2004

\title{
Distribution, Habitat Use, Growth, and Condition of a Native and an Introduced Catfish Species in the Hudson River Estuary
}

Stephen M. Jordan

Robert M. Neumann

Eric T. Schultz

University of Connecticut-Storrs, eric.schultz@uconn.edu

Follow this and additional works at: https://opencommons.uconn.edu/eeb_articles

Part of the Aquaculture and Fisheries Commons, Population Biology Commons, and the Zoology Commons

\section{Recommended Citation}

Jordan, Stephen M.; Neumann, Robert M.; and Schultz, Eric T., "Distribution, Habitat Use, Growth, and Condition of a Native and an Introduced Catfish Species in the Hudson River Estuary" (2004). EEB Articles. 39.

https://opencommons.uconn.edu/eeb_articles/39 


\title{
Distribution, Habitat Use, Growth, and Condition of a Native and an Introduced Catfish Species in the Hudson River Estuary
}

\author{
Stephen M. Jordan a and Robert M. Neumann ${ }^{\mathrm{b}}$ \\ Department of Natural Resources Management and Engineering \\ University of Connecticut, Storrs, Connecticut 06269-4087 USA \\ and \\ Eric T. Schultz \\ Department of Ecology and Evolutionary Biology \\ University of Connecticut, Storrs, Connecticut 06269-3043 USA
}

\begin{abstract}
White catfish (Ameiurus catus) is native to the Hudson River and is now coexisting with the recently established channel catfish (Ictalurus punctatus). These species were sampled from four freshwater reaches and four habitat types of the Hudson River estuary to assess whether the two species overlapped in their habitat use, and whether any impact on the native species was evident. Catfishes were sampled in 1998 and 1999 using baited hoop nets ( $N=708$ net nights). Catch-per-unit-effort (CPUE, number of fish per net night; total catch $=368$ ) of white catfish was significantly different among reaches and habitat types; CPUE was greatest in the upstream reach, and in offshore shoal habitat. Channel catfish (total catch $=344$ ) were more abundant in offshore shoal habitats in upriver reaches, but were more abundant in nearshore and tributary mouth habitats in downstream reaches. Individuals of both species were largest upstream. Individual condition (as relative weight, $W r$ ) varied with reach in white catfish, and was low in a downstream reach; in contrast, $W r$ did not vary among reaches in channel catfish. White catfish grew slowly compared to channel catfish. Relative to populations in other water bodies in North America, Hudson River fishes of both species grew slowly in their first year, but otherwise grew at expected rates. Channel catfish are becoming more abundant in the Hudson River, as white catfish appear to decline.

Channel catfish establishment may be facilitated by greater flexibility in habitat use.
\end{abstract}

\section{INTRODUCTION}

This study was undertaken to determine the current status of two species of catfish in the Hudson River estuary, the white catfish (Ameiurus catus) and the channel catfish (Ictalurus punctatus); the former is native to the estuary, whereas the latter has been recently introduced. The Hudson River estuary extends from the Troy Lock and Dam at Albany to the mouth of the river in New York Bay, comprising a range of salinity and a wide range of habitats, including tidal flats, backwater coves, shoals, and deep channels
(Cooper et al. 1988). Given recent sharp increases in channel catfish abundance in the estuary, there is interest in determining whether the two species overlap in their habitat use, and whether any impact on the native species is evident. The specific objectives of the research were to (1) compare relative abundance and size structure of catfishes among river reaches; (2) determine habitat associations; and (3) quantify growth rate and body condition of catfishes.

\footnotetext{
Present address: Keane, Inc., 100 Corporate Place, Century Executive Park, Rocky Hill,
Connecticut 06067 b Present address: Fisheries and Illinois Aquaculture Center, Department of Zoology,
Southern Illinois University, Carbondale, Illinois 62901-6511
} 
Channel catfish is the most studied catfish species in North America (Irwin and Hubert 1999). It has been widely introduced outside its native range, including the Hudson River. The channel catfish was not reported in the Hudson River before 1979 (Beebe and Savidge 1988) but has been consistently recorded since (ASA Analysis and Communication 2003). In rivers, adult channel catfish use a variety of habitats including mainstreams (Dames et al. 1989), pools (Aadland 1993), and areas with natural and artificial cover (Layher and Maughan 1985). Channel catfish spawn in late spring, generally in or around protective cover (Gerhardt and Hubert 1990, Hubert 1999). Juvenile channel catfish used shallow habitats with slow velocities at night and main channel habitats during the day (Irwin et al. 1999).

White catfish is recreationally and economically important across its range and is native to Atlantic coastal drainages from New York to Florida, including the Hudson River (Schmidt 1986). White catfish population structure and life history were assessed in the Hudson River estuary in the early 1980's by Hughes and Carlson (1986), roughly coincident with the first appearance of the channel catfish. They found that white catfish spawned in shoal and rock pile habitats during the months of June and July, and the upper Hudson River estuary (above km 201) was the primary spawning area. These catfish were found predominantly in shoal and channel border areas throughout the year but were occasionally captured in vegetated backwater areas.

\section{METHODS AND MATERIALS}

\section{Study sites and fish sampling}

Four reaches of the Hudson River estuary were sampled, extending from Troy Lock and Dam (river km 246; hereafter, R1) downstream to Newburgh (river km 85; hereafter, R4). All reaches were freshwater and tidal and varied in their physical characteristics. $\mathrm{Rl}(\mathrm{km} \mathrm{226-246)}$ was less than $0.5 \mathrm{~km}$ wide and shallower than $10 \mathrm{~m}$ in most sections, was channelized, had few tidal flats, had no backwaters, and contained a tailrace habitat below the lock and dam. The upstream limit of the $14.3 \mathrm{~m}$ navigation channel that is dredged throughout the Hudson River estuary is at the downstream end of

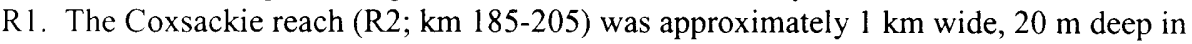
many sections, and contained many islands, tidal flats, and vegetated backwater areas. The Kingston reach (R3; km 135-155) was approximately $1.5 \mathrm{~km}$ wide, over $30 \mathrm{~m}$ deep in some sections, and had large tidal flats and extensive vegetated backwater areas. R4 ( $\mathrm{km} \mathrm{85-105)} \mathrm{was} \mathrm{approximately} 2 \mathrm{~km}$ wide, over $40 \mathrm{~m}$ deep in some sections, and contained expansive tidal flats but little vegetated backwater areas.

Catfishes were sampled from July to September 1998 and May to August 1999 using hoop nets. However, most sampling occurred during June to August of each year. Only the Troy and Coxsackie reaches were sampled in 1998, while all reaches were sampled in 1999. Hoop nets had a 0.9-m opening, 1.9-cm bar mesh, and were baited with cheese trimmings. Nets were set for $24 \mathrm{~h}$ and anchored to prevent their collapse with the changing tides. The total lengths and weights of all captured fishes were recorded. The right pectoral spines of five fish per 1-cm length group were removed using the methodology described by Sneed (1951).

Catfishes were sampled from tributary mouths, channel border/shoal areas (bottom shallower than the 9.8-m navigation channel but generally deeper than $4 \mathrm{~m}$ ), and nearshore areas in all reaches. Mid-channel habitat was not sampled due to the potential conflicts with navigation and because depths were often prohibitive to effectively set hoop nets. The tailrace in R1 was also sampled. Usually, 12 nets per night were divided evenly among randomly selected habitats of each type within a reach. To select nearshore and shoal sampling locations, a global positioning system was used to locate a randomly selected latitudinal transect, and a hoop net was set in a shoal and nearshore habitat along that transect. 
Relative abundance was indexed using catch-per-unit-effort (CPUE; number of

fish per net night). Catch-per-unit-effort data deviated substantially from normality; thus, differences in mean CPUE among reaches and habitats were tested using the nonparametric two-way Friedman's test. Because only R1 and R2 were sampled in 1998 and all reaches were sampled in 1999, CPUE data for both years were combined to compare CPUE among reaches and among the three habitat types common to all reaches. An additional one-way Kruskal-Wallis test was used to test for differences among the four habitat types in R1. Multiple comparisons were performed using Fisher's Least Significant Difference Test. Statistical analyses were performed using the Statistical Analysis System (SAS Institute 1991)

Size structure was described using length-frequency histograms. Analysis of size structure was confined to only 1999 samples, because of evident inter year differences and larger sample sizes in that year. Insufficient sample sizes in some reaches necessitated pooling length-frequency data for the two upstream (R1 and R2) and two downstream reaches ( $\mathrm{R} 3$ and $\mathrm{R} 4$ ), which were then compared using KolmogorovSmirnov tests. Body condition was quantified using the relative weight $(W r)$ index (Wege and Anderson 1978). Standard weight equations were $\log _{10} W s=-5.851+$ $3.395 \log _{10} \mathrm{TL}$ for white catfish (Bister et al. 1999) and $\log _{10} W s=-5.800+3.294 \log _{10} \mathrm{TL}$ for channel catfish (Brown et al. 1995), where $W s$ is in $\mathrm{g}$ and TL is total length in $\mathrm{mm}$. Relative weight values below 100 may indicate problems with food or feeding conditions (Anderson and Neumann 1996). Among fish larger than $200 \mathrm{~mm}$, relative weight data were normally distributed and did not covary with length; hence, differences in mean $\mathrm{Wr}$ using Fisher's Least Significant Difference Test.

Catfish spines were sectioned at the distal end of the basal groove (Sneed 1951, Marzolf 1955) at a thickness of approximately $0.60 \mathrm{~mm}$ using a low-speed saw. Sections were affixed to microscope slides and annular measurements were obtained using an image analysis system. Back-calculated length-at-age was determined using the direct proportion method assuming a zero intercept (DeVries and Frie 1996) and was consistent with back-calculation methods previously used to describe white catfish age and growth in the Hudson River (Hughes and Carlson 1986).

\section{RESULTS AND DISCUSSION}

Hoop nets were set for 708 net nights, and 368 white catfish and 344 channel catfish were captured (Table 1). During one sampling period (representing 22 net nights) in May 1999, 117 white catfish were captured in reach RI. This unusually large sample represented approximately one third of the entire white catfish catch and appeared to be due to high movement rates associated with a single high discharge event or with spawning activity. Thus, the sample obtained on that day was considered an outlier and was excluded from CPUE analyses; individuals from that sample were used in size structure, body condition, and age and growth analyses.

\section{Relative abundance among reaches and habitats}

Mean CPUE of white catfish was significantly different among reaches $(P<0.0001)$ and habitat types $(P=0.012)$, and the reach*habitat type interaction was not significant $(P>0.05)$. Mean CPUE was significantly greater in reach $\mathrm{R} 1$ compared to all other reaches (Fig. 1). The abundance of white catfish was significantly greater in the shoals habitat, compared to nearshore and tributary mouth habitats over all reaches, and compared to nearshore, tributary mouth, and tailrace habitats in reach $\mathrm{R} 1(P=0.0021)$. This pattern of habitat use and along-estuary distribution is consistent with previous 
Table 1. Reaches and habitats sampled, number of hoop net nights, and number of white catfish and channel catfish captured in the Hudson River, New York.

\begin{tabular}{llccc}
\hline Reach & Habitat type & Net-nights & White catfish & Channel catfish \\
\hline Troy (R1) & Nearshore & 53 & 21 & 22 \\
& Shoal & 43 & 72 & 44 \\
& Tributary mouth & 54 & 14 & 42 \\
& Tailrace & 27 & 14 & 18 \\
Coxsackie (R2) & Nearshore & 119 & 33 & 46 \\
& Shoal & 80 & 33 & 49 \\
& Tributary mouth & 55 & 7 & 14 \\
Kingston (R3) & Nearshore & 71 & 12 & 10 \\
& Shoal & 46 & 7 & 4 \\
\multirow{5}{*}{ Newburgh (R4) } & Tributary mouth & 20 & 3 & 3 \\
& Nearshore & 47 & 12 & 45 \\
& Shoal & 42 & 17 & 13 \\
Total & Tributary mouth & 29 & 6 & 34 \\
& Total & 686 & 251 & 344 \\
\hline
\end{tabular}
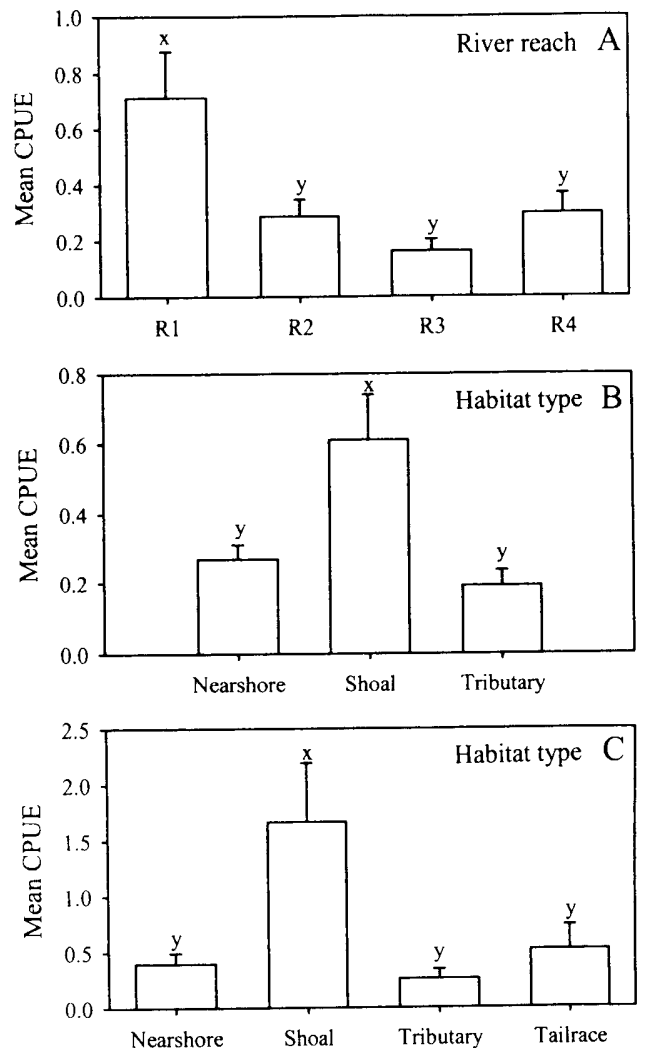

Figure 1. Mean catch-per-unit effort (CPUE; number of fish per net night) of white catfish in four reaches of the Hudson River (A), in three habitat types common to all reaches (B), and in four habitat types in the Troy reach $(C)$. $R 1=$ Troy, R2=Coxsackie, R3=Kingston, R4=Newburgh. Means sharing the same letters are not significantly different $(P>0.05)$. 
findings in the Hudson River. Hughes and Carlson (1986) found that white catfish were mostly captured in offshore shoal and rock pile habitats, with lesser catches in vegetated backwater areas. They also found that most spawning of white catfish occurred in upstream reaches of the Hudson River estuary during June and July, which may explain why mean CPUE was highest in the Troy reach. Most sampling during this study occurred from June to August when white catfish were likely to be in upper reaches of the estuary.

Channel catfish were most abundant in a different habitat in the downstream reaches, providing evidence for limited spatial segregation of the two catfish species. The highest CPUE of channel catfish shifted from shoals in upstream reaches to nearshore and tributary mouth habitats in downstream reaches (Fig. 2). There was a significant interaction $(P=0.0082)$ of CPUE among reaches and habitat types. One-way Kruskal-Wallis tests were used to test for differences in CPUE in the same habitats among reaches and among habitats within each reach. In the nearshore habitat, abundance was greater in $\mathrm{R} 4$ than in other reaches $(P=0.012)$, whereas in the shoal habitat, abundance was greatest in $\mathrm{R} 1(P=0.0002)$. Channel catfish relative abundance tended to be highest in reaches R1 and R4 for all habitats. No differences in CPUE among habitats were found for reaches R1 to R3. However, in reach R4, relative abundance of channel catfish was higher in nearshore and tributary mouth habitats, compared to shoals $(P=0.037)$.
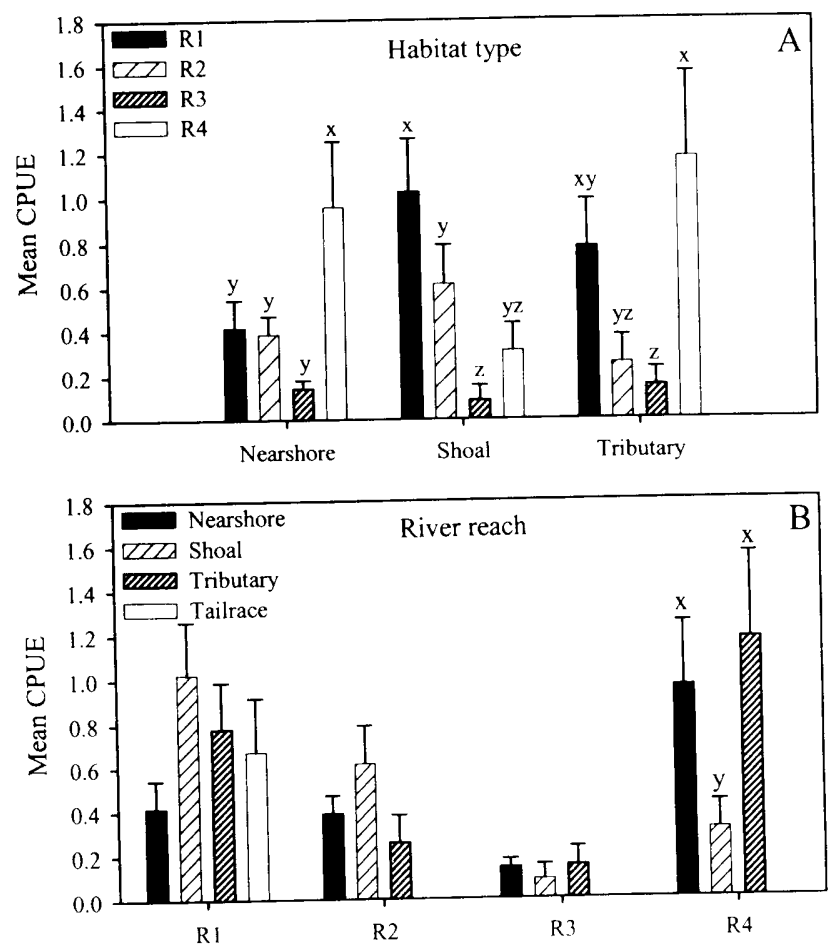

Figure 2. Mean catch-per-unit effort (CPUE; number of fish per net night) of channel catfish in three habitat types among reaches of the Hudson River (A), and among habitat types within each reach (B). R1=Troy, $\mathrm{R} 2=$ Coxsackie, R3=Kingston, R4=Newburgh. Means sharing the same letters are not significantly different $(P>0.05)$. 
Population characteristics

Both species showed a pronounced along-estuary change in size distribution. The size ranges in upstream and downstream reaches were comparable; however, smaller size classes of both species were most abundant in downstream reaches, while intermediate and large white and channel catfish were most abundant upstream (differences in size distribution $P<0.0001$; Fig. 3).

Differences in size structure of both species between the upstream and downstream reaches may reflect size-related patterns in food availability and behavior. The largest fish of both species shared moderately deep shoal habitat in R1. This reach has moderately deep shoal and old channel habitat but lacks tidal flats and backwaters. Carlson (1989) found a high abundance of clupeids during spring at Troy Lock and Dam, and large catfishes may be taking advantage of feeding on a high concentration of prey fish. This reach may also function as a spawning ground for both species. The lower reaches have a wider range of habitats, with expansive tidal flats and low velocity zones in addition to the navigation channel and deeper shoals. Juvenile fishes favored low velocity shore zones in the Hudson River (Gladden et al. 1988, Beebe and Savidge 1988), possibly because of shelter from predation as well as high rates of invertebrate production in tidal flat areas.

There was an along-river effect on condition in white catfish. For both species, mean $W r$ was above 90 in most reaches, indicating fish were in fair condition. However, mean $W r$ of white catfish in R3 was below 90 and was lower than in R1 $(P=0.001)$. Relative weight is related to growth rate and prey availability in several fish species
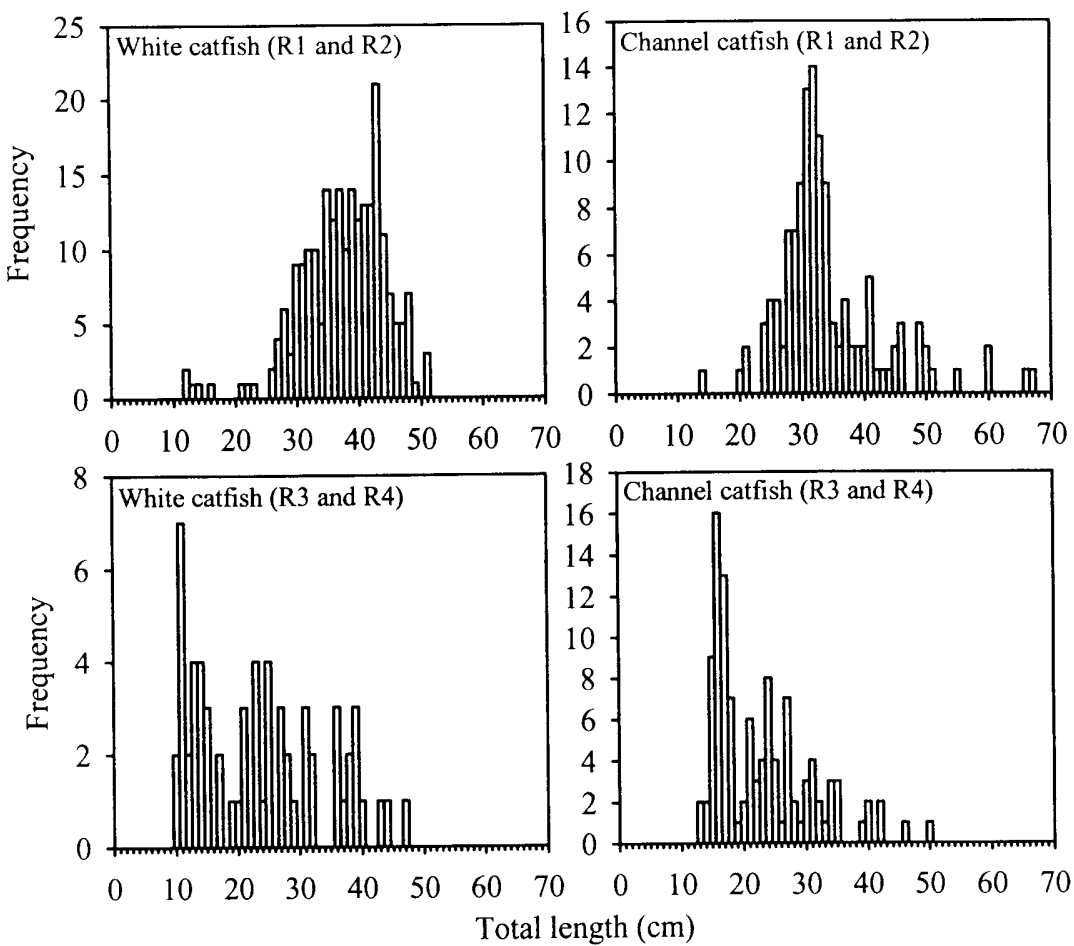

Figure 3. Length-frequency histograms for white catfish and channel catfish captured in the upper reaches (R1 and R2) and the lower reaches (R3 and R4) of the Hudson River estuary, 1999. 
(Blackwell et al. 2000), and lower $W r$ values in R3 may be indicative of lower food availability compared to other reaches. There were no significant differences in $\mathrm{Wr}$ among reaches for channel catfish. Taking these results in conjunction with the observation that channel catfish in downriver reaches shifted to nearshore habitats while white catfish remained in offshore shoals, suggests that channel catfish are more flexible in habitat use according to feeding opportunity. The readiness with which this species becomes established in new rivers may be attributable to this adaptability.

White catfish are slow growing and long lived compared to channel catfish in the Hudson River (Table 2). White catfish reached stock length $(20 \mathrm{~cm})$ by age 3 and quality length $(33 \mathrm{~cm})$ by age 6 . The maximum age observed for white catfish during this study was 14 years, while Hughes and Carlson (1986) aged white catfish to eight years. In the Hudson River, channel catfish reached stock length $(28 \mathrm{~cm})$ by age 3 and quality length $(41 \mathrm{~cm})$ by age 5 . The oldest channel catfish captured was eight years, which is near the maximum age in many water bodies in North America (Hubert 1999). For both species, growth to age 1 appeared slow in the Hudson River, while lengths at ages greater than age 1 were similar to those reported for other waterbodies in North America.

The introduction and proliferation of channel catfish in the Hudson River could have impacts on other benthic species. Channel catfish can thrive in a wide range of environmental conditions (Hubert 1999) and is becoming well established in rivers in the northeastern U.S. In the Hudson River, the channel catfish was rare in trawl catches through the early 1990's, but its abundance has been increasing consistently since (ASA Analysis and Communication 2003). In the Connecticut River, Connecticut, the channel catfish was relatively uncommon in the early 1970's but now outnumbers white catfish in northern and central areas of the river by 59\% (Jacobs and O'Donnell 1996). In the upper Delaware River, there has been a similar shift in relative abundance of the two species (S. Jinks, ASA Analysis and Communication, pers. comm.). While white catfish abundance has fluctuated periodically, the overall abundance of this species has declined coincident with channel catfish establishment.

Table 2. Mean back-calculated length-at-age $(\mathrm{mm})$ of white catfish and channel catfish up to age 8 in the Hudson River, 1998 and 1999.

\begin{tabular}{lccccccccc}
\hline & & \multicolumn{10}{c}{ Age } \\
\cline { 2 - 10 } Site & $N$ & 1 & 2 & 3 & 4 & 5 & 6 & 7 & 8 \\
\hline White catfish & 169 & 72 & 154 & 233 & 285 & 321 & 349 & 372 & 391 \\
Channel catfish & 140 & 79 & 208 & 300 & 388 & 456 & 511 & 521 & 556 \\
\hline
\end{tabular}

\section{ACKNOWLEDGMENTS}

Funding for this research was provided by the Hudson River Foundation for Science and Environmental Research grant number 009/98A. Field and laboratory assistance was provided by P. Saccante, L. DiTomasso, and K. Vensel. We are grateful to John Young and Steve Jinks, ASA Analysis and Communications, for furnishing data from the Hudson River Estuarine Monitoring Program.

\section{LITERATURE CITED}

Aadland, L. P. 1993. Stream habitat types: their fish assemblages and relationships to flow. North American Journal of Fisheries Management 13:790-806.

Anderson, R. O. and R. M. Neumann. Length, weight and associated structural indices. Pages 447-482 in B. R. Murphy and D. W. Willis, editors. Fisheries techniques, second edition. American Fisheries Society, Bethesda, Maryland. 
ASA Analysis and Communication. 2003. 2000 year class report for the Hudson River Estuary Monitoring Program, New Hampton, NY.

Beebe, C. A. and I. R. Savidge. 1988. Historical perspective on fish species composition and distribution in the Hudson River estuary. American Fisheries Society Monograph 4:25-36.

Bister, T. J., D. W. Willis, M. L. Brown, S. M. Jordan, R. M. Neumann, M. C. Quist, and C. S. Guy. 2000. Proposed standard weight $\left(W_{S}\right)$ equations and standard length categories for 18 warmwater nongame and riverine fish species. North American Journal of Fisheries Management 570-574.

Blackwell, B. G., M. L. Brown, and D. W. Willis. 2000. Relative weight (Wr) status and current use in fisheries assessment and management. Reviews in Fisheries Science 8:1-44.

Brown, M. L., F. Jaramillo, Jr., D. M. Gatlin III, and B. R. Murphy. 1995. A revised standard weight $(W s)$ equation for channel catfish. Journal of Freshwater Ecology 10(3):295-302.

Carlson, D. M. 1989. Fish and their habitats in the upper Hudson estuary. New York State Department of Environmental Conservation, Albany, New York.

Cooper, J. C., F. R. Cantelmo, and C. E. Newton. 1988. Overview of the Hudson River estuary. American Fisheries Society Monograph 4:11-24.

Dames, H. R., T. G. Coon, and J. W. Robinson. 1989. Movements of channel and flathead catfish between the Missouri River and a tributary, Perche Creek. Transactions of the American Fisheries Society 118:670-689.

DeVries, D. R. and R. V. Frie. 1996. Determination of age and growth. Pages 483-512 in B. R. Murphy and D. W. Willis, editors. Fisheries techniques, second edition. American Fisheries Society, Bethesda, Maryland.

Gerhardt, D. R. and W. A. Hubert. 1991. Population dynamics of a lightly exploited channel catfish stock in the Power River system, Wyoming-Montana. North American Journal of Fisheries Management 11:200-205.

Gladden, J. B., F. R. Cantelmo, J. M. Croom, and R. Shapot. 1988. Evaluation of the Hudson River ecosystem in relation to the dynamics of fish populations. American Fisheries Society Monograph 4:37-52.

Hubert, W. A. 1999. Biology and management of channel catfish. American Fisheries Society Symposium 24:3-22.

Hughes, M. J. and D. M. Carlson. 1986. White catfish growth and life history in the Hudson River estuary, New York. Journal of Freshwater Ecology 3(3):407-418.

Irwin, E. R. and W. A. Hubert. 1999. Biology and management of ictalurids: a summary of the proceedings of the international catfish symposium. American Fisheries Society Symposium 24:495-500.

Irwin, E. R., M. C. Freeman, and K. M. Costley. 1999. Habitat use by juvenile channel catfish and flathead catfish in lotic systems in Alabama. American Fisheries Society Symposium 24:223-230.

Jacobs, R. P. and E. B. O’Donnell. 1996. An electrofishing survey of selected Connecticut lakes. Federal Aid in Sport Fish Restoration Final Report F-57-R-14. Department of Environmental Protection, Hartford, Connecticut.

Layher, W. G. and O. E. Maughan. 1985. Relations between habitat variables and channel catfish populations in prairie streams. Transactions of the American Fisheries Society 114:771-781.

Marzolf, R. C. 1955. Use of pectoral spines and vertebrae for determining age and rate of growth of the channel catfish. Journal of Wildlife Management 19:243-249.

SAS Institute. 1991. SAS/STAT user's guide, $4^{\text {th }}$ edition. SAS Institute, Cary, North Carolina. 
Schmidt, R. E. 1986. Zoogeography of the northern Appalachians. Pages 137-159 in C. H. Hocutt and E. O. Wiley, editors. The zoogeography of North American freshwater fishes. John Wiley and Sons, New York.

Sneed, K. E. 1951. A method for calculating the growth of channel catfish, Ictalurus lacustris punctatus. Transactions of the American Fisheries Society 80:174-183.

Wege, G. J. and R. O. Anderson. 1978. Relative weight $(\mathrm{Wr})$ : a new index of condition for largemouth bass. Pages 79-91 in G. D. Novinger and J. G. Dillard, editors. New approaches to the management of small impoundments. American Fisheries society, North Central Division, Special Publication 5, Bethesda, Maryland. 